\title{
GEOLOGY AND MINERALOGY OF GEMMING TERRAINS OF SRI LANKA
}

\author{
KAPILA DAHANAYAKE and A. P. RANASINGHE
}

\begin{abstract}
DAHANAYAKE, KAPILA and RANASINGHE, A. P., 1985: Geology and mineralogy of gemming terrains of Sri Lanka. Bull. Geol. Soc. Finland 57, Part $1-2,139-149$.

Gemming in Sri Lanka is carried out in river valleys and on hill slopes underlain by high grade Precambrian metasedimentary rock suites. The principal gem mineral, corundum, is mined from assemblages rich in garnet, spinel, topaz, tourmaline and zircon occurring as residual, eluvial or alluvial deposits. Mineralogical studies of the rocks of the drainage basins of the gemming terrains reveal that gemstones are derived from garnetiferous gneisses, granulites and charnockites the latter being exceptionally rich in corundum, hypersthene and sillimanite when poor in quartz. Thus a desilication process under high temperature-pressure conditions is attributed to the formation of Sri Lanka's principal gemstones.
\end{abstract}

Key words: Ratnapura, Kalu Ganga, gemming, granulite, gemstones, corundum.

Kapila Dahanayake: Department of Geology, University of Peradeniya, Peradeniya, Sri Lanka and A. P. Ranasinghe: Water Resources Board, Puttalam, Sri Lanka.

\section{Introduction}

Gemming has been carried out in Sri Lanka for more than twenty centuries in the district of Ratnapura (Sinhalese: city of gems) lying towards the southwest of the central highlands of the country. However, for nearly twenty years now another area towards the northeast of the island, on the banks of the Kalu Ganga, has become a centre of large-scale gemming. During recent times, gems have been located in most terrains underlain by the Highland Group of metasedimentary rock suites, most of which belong to the high temperature - high pressure granulite facies $\left(\mathrm{P}-3\right.$ to $7 \mathrm{~kb}$ and $\mathrm{T}-700^{\circ}$ to $840{ }^{\circ} \mathrm{C}$, Katz 1972; Hapuarachchi 1975; Jaya- wardena and Carswell 1976). Highland Group rocks occur in the central highlands of Sri Lan$\mathrm{ka}$ and are bounded on either side by granites, migmatites and gneisses, mostly of the amphibolite facies and collectively referred to as the Vijayan Complex (Cooray, 1978; Fig. 1). The Highland rocks are characterized by metasedimentary suites consisting of quartzite, marble, granulite, garnetiferous gneiss, calc gneiss and charnockite.

The principal Sri Lankan gem mineral, corundum, was observed in granulites associated with limestones by Coomaraswamy (1903), who attributed its occurrence to local variations in the constitution of a consolidating magma. Coates (1935) described corundum crystals as- 
sociated with feldspar and biotite bordering a sill-like biotite pegmatite in decomposed granulite. Wells (1956) noted occurrences of corundum and sillimanite in rock suites of pyroxene granulites. The same author observed corundun in association with crystalline limestone and a syenite, and its formation was attributed to desilication of syenite magma by limestone. Cooray and Kumarapeli (1960) also observed corundum in biotite gneiss interbedded with charnockites. Corundum in thin section was observed by the same authors in a groundmass of feldspar devoid of any quartz. Silva (1976) noted corundum in skarn-type marble bordering granitic intrusions. Dahanayake and Ranasinghe (1981) reported corundum from crushed rock samples and sediments collected from the catchment areas of two rivers draining a terrain underlain largely by garnetiferous gneisses and granulites. Munasinghe and Dissanayake (1981) believed that the corundum in Sri Lankan rocks formed after a process of desilication caused by contact metamorphic effects of charnockites and other basic intrusions.

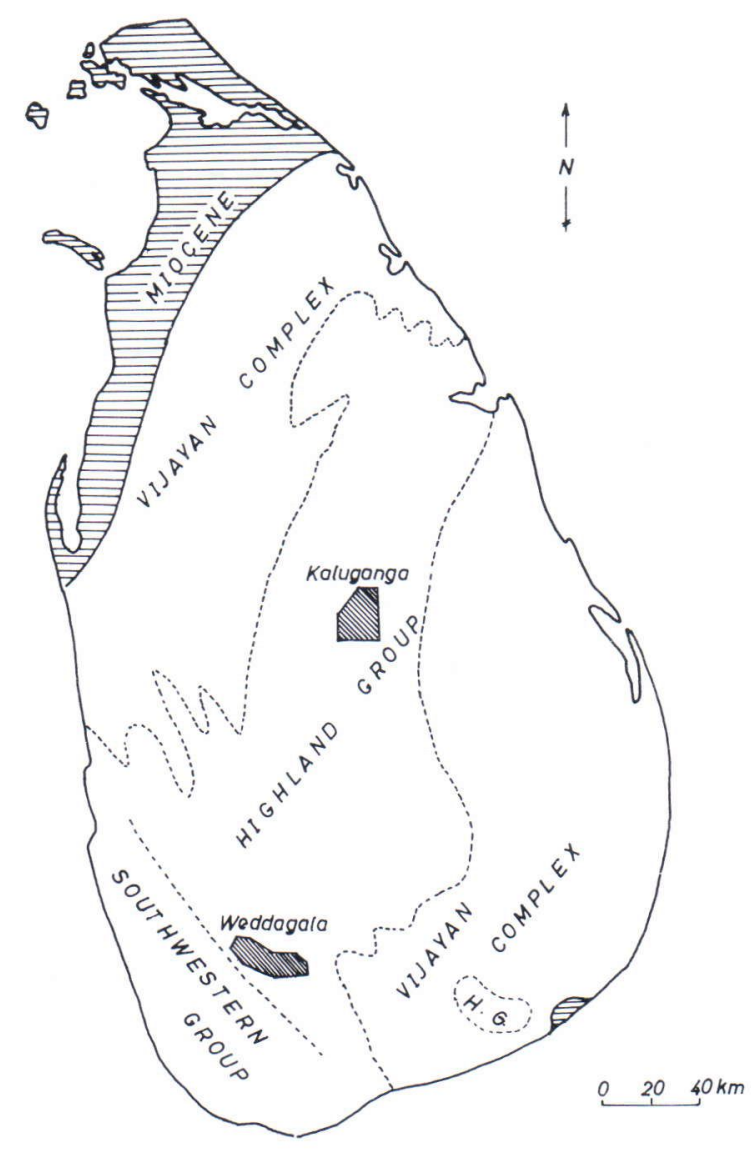

Fig. 1. Outline geological map of Sri Lanka indicating the major geological units and the two study areas Weddagala (Rakwana topographical map sheet) and Kalu Ganga (Elahera topographical map sheet). 
The authors of the present work consider the geology and mineralogy of two popular gemming areas - Weddagala and Kalu Ganga both of which lie in the Highlands of Sri Lanka. The emphasis is on the mineral fraction of both lithological units and overlying sediments. This paper is dedicated to the memory of Professor Th. G. Sahama who was fascinated by the quality and quantity of the minerals in the gem sediments in these two gemming terrains, which he visited a few weeks before his sad demise.

\section{Methods of study}

After an initial phase of laboratory studies involving aerial photographic interpretation at a scale of $1: 40,000$, geological mapping was undertaken in the two gemming areas. A geological map at a scale of $1: 63,360$ was thus prepared for each area. During the field studies, more than 200 gem pits were studied for their stratigraphy and sedimentology.

The crushed rock samples and sediments were analysed mechanically using sieves and ro-tap. The $-80+120$ fraction was selected for detailed heavy mineral studies with bromoform as the separating medium. After the magnetic portion had been removed using a hand magnet, the residue was treated with a Frantz isodynamic separator. The apparatus was set with forward and side tilts at $20^{\circ}$, and a magnetic product was taken at 0.4 amperes. Subsequent separations were done at $0.8,1.0$ and 1.2 amperes, the side tilt being kept at $5^{\circ}$ for the 1.0 and 1.2 current values. The products were weighed and split into about 500 grains using a multiple cone separator. The grains were then mounted in

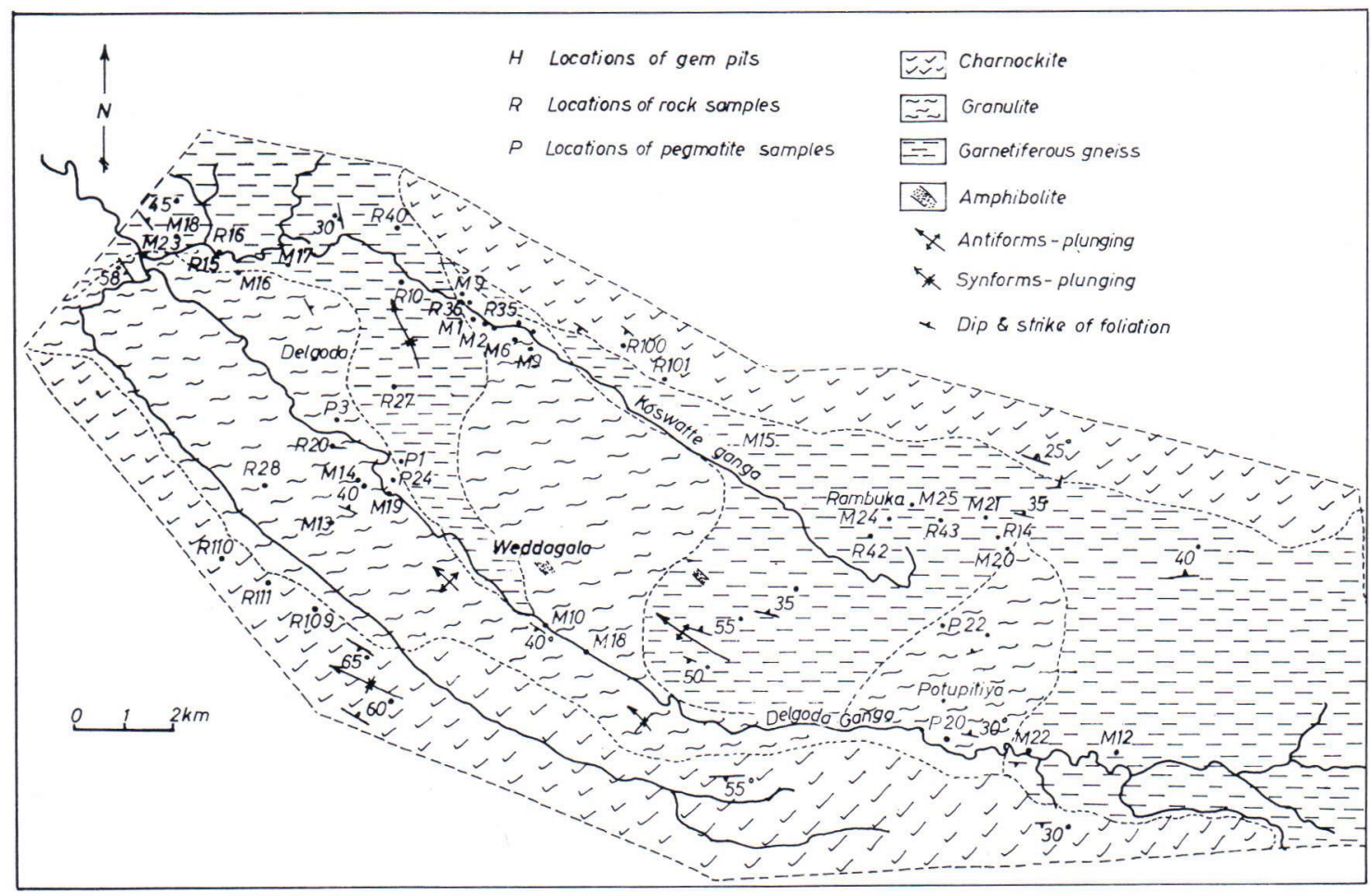

Fig. 2. Geological map of Weddagala area (modified after Dahanayake and Ranasinghe 1981). 
Canada balsam on glass slides fitted with a grid. The different minerals were thus identified and counted. Their volume percentages were noted and the weight percentages were computed. The minerals were identified under binocular and petrographic microscopes.

\section{Geology of study areas}

\section{Weddagala (Fig. 2)}

This area lies in the Ratnapura district of Sri Lanka and is overlain by the topographic sheet of Rakwana (1: 63,360). The Weddagala region is characterized by ridge and valley topography with maximum elevations of $1060 \mathrm{~m}$ above
MSL and a local relief varying between $300 \mathrm{~m}$ and $800 \mathrm{~m}$. The ridges are formed mainly by charnockites, the valleys being underlain mostly by garnetiferous gneiss and granulite. Amphibolitic and charnockitic bands are found interlayered within gneisses and granulites. These lithological units trend NW-SE and give rise to northward - plunging synforms and antiforms. Three major joint patterns characterize the said rock types.

Gemming in the study area of Weddagala is carried out on the banks of the Delgoda Ganga and the Koswatte Ganga, two major streams draining the area. Most of the gem sediments are of the alluvial type described earlier by Dahanayake et al., (1980). However, sediments of the eluvial type are also mined on the slopes of ridges (Fig. 3a, b, c).

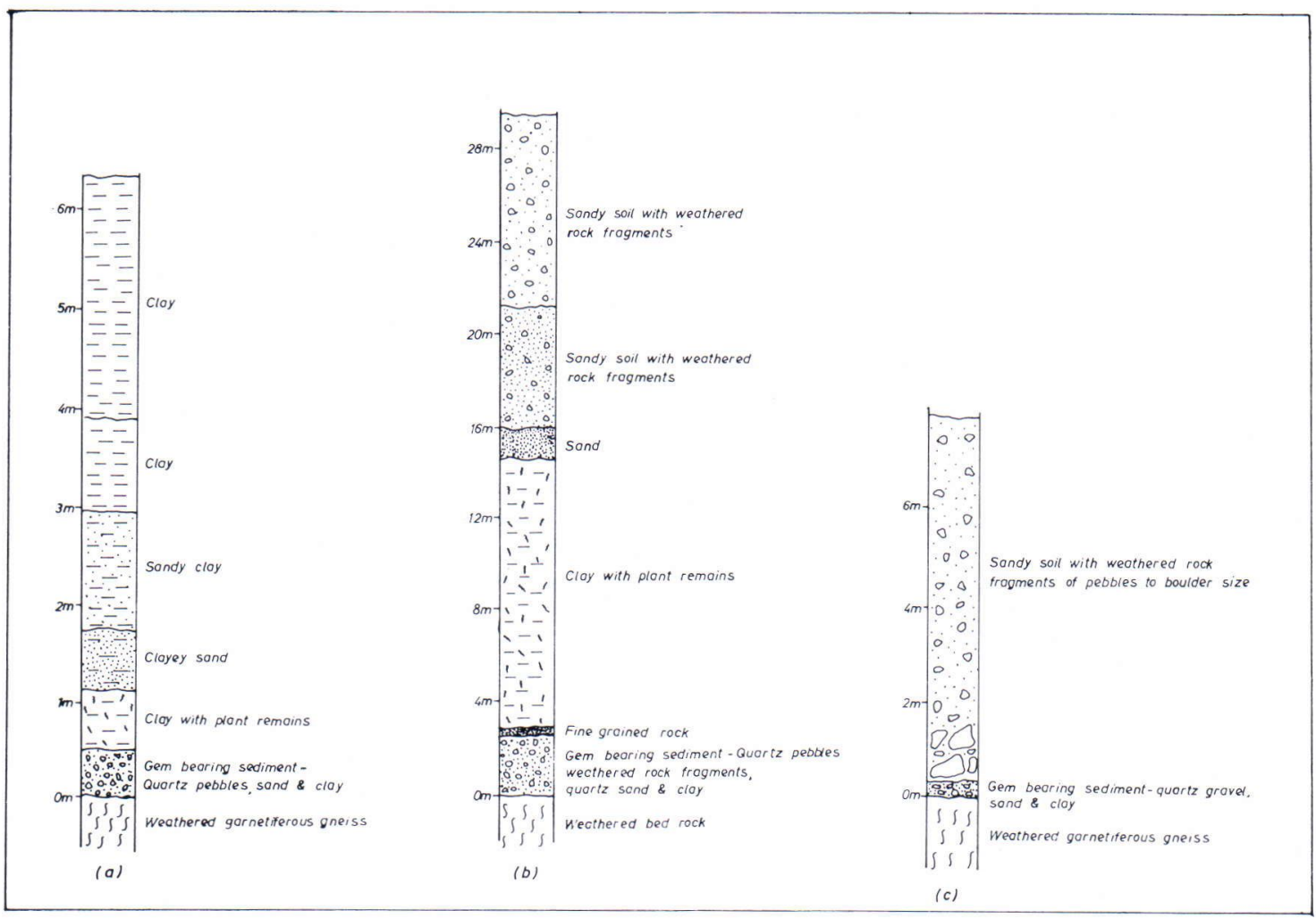

Fig. 3. Stratigraphic sections of gem pits - Weddagala (a) alluvial type (b) alluvial pit showing transformation to eluvial type towards the top (c) eluvial type (modified after Dahanayake et al., 1980). 
The gem-bearing sediments of alluvial-type pits occur on weathered bed rocks and are composed mainly of rounded quartz pebbles, sand and clay found in beds ranging in thickness from $10 \mathrm{~cm}$ to $1 \mathrm{~m}$ or even more. The texture of the sediments implies long distances of transport. The sediments form discontinuous beds and resemble modern river sediments. The overlying material consists of sand, clay and plant debris and forms beds from 2 to $30 \mathrm{~m}$ in thickness.

The eluvial-type gem sediments lie on weathered bedrock, which in places is lateritic in character. The gem-bearing beds are relatively thin and discontinuous and occur as pockets trapped within large rock fragments and boulders. Such beds are composed of weathered rock fragments, sub-rounded quartz gravels, sand and

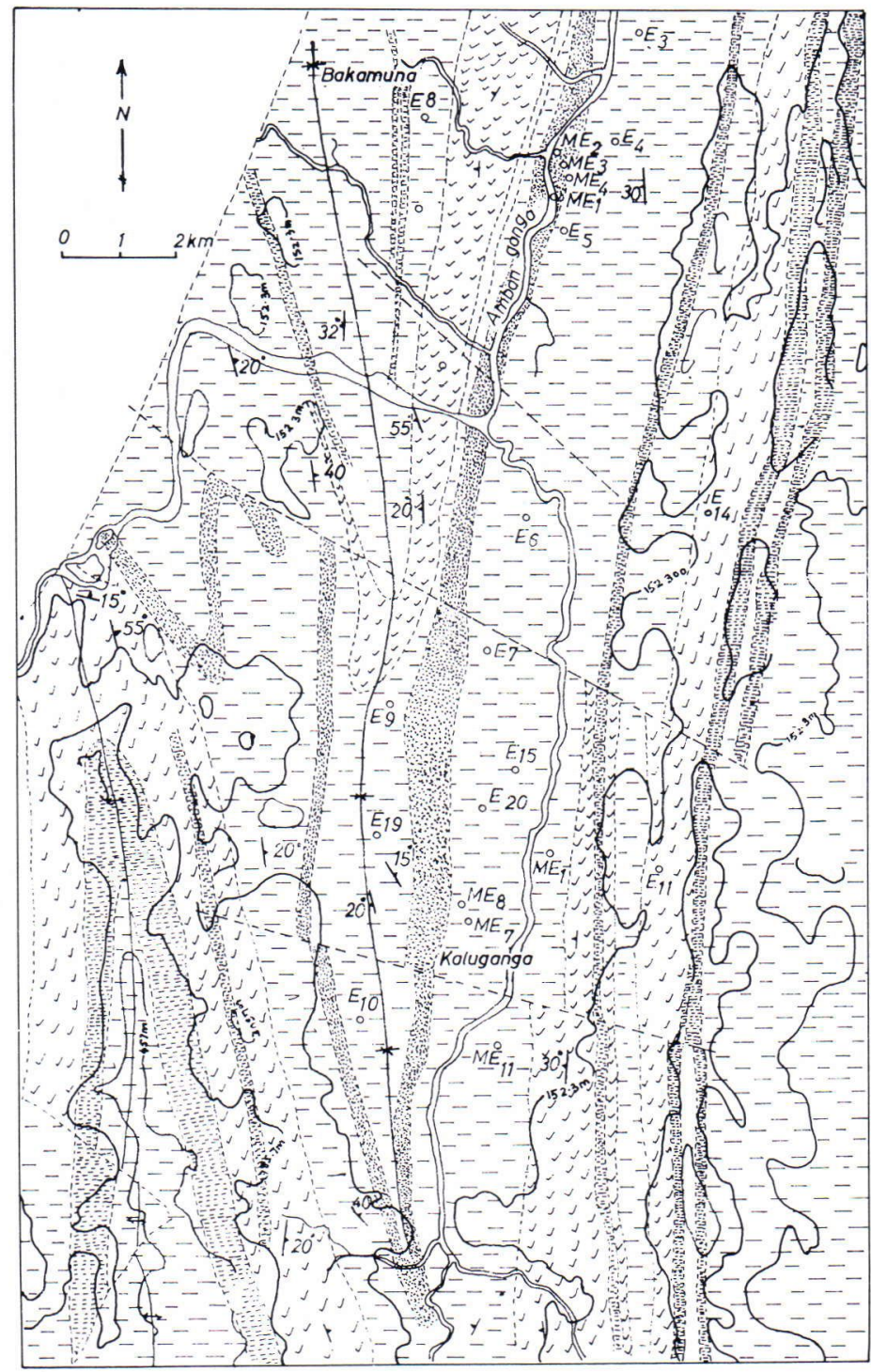

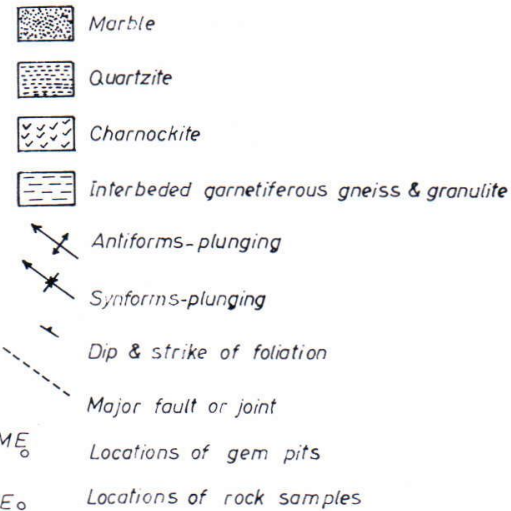

Fig. 4. Geological map of the Kalu Ganga area. 
clay. The overlying material consists of sandy soil with weathered rock fragments of pebble to boulder size. Lateritic soils, too, are noted in places. The sorting in these soils is very poor, and distinct bedding features have not been observed.

\section{Kalu Ganga (Fig. 4)}

The Kalu Ganga area lies in the Matale district of Sri Lanka and is covered by the topographic sheet of Elahera $(1: 63,360)$. This region also is characterized by ridge and valley topography but the valleys are relatively wider and form extensive flat terrains. The maximum elevation noted is about $450 \mathrm{~m}$ above MSL and the local relief ranges from 250 to $300 \mathrm{~m}$. Charnockites and quartzites form elongated ridges, the valleys being underlain by marble, garnetiferous gneiss or granulite. Amphibolitic, charnockitic and granitic bodies are found as conformable and cross-cutting structures. The lithological units generally follow a NS trend and form northward-plunging synforms and antiforms.

Gem mining is common on the banks of the Kalu Ganga and the Amban Ganga and in the adjacent valleys. The bank sediments are of the alluvial type whereas those towards the hill slopes are of the residual type (Dahanayake et al. 1980) (Figs. 5a, b).

Alluvial gem-bearing pits are located close to the rivers and they contain rounded and subrounded quartz pebbles, sand and clay. These sediments, which lie on weathered bedrock, form beds about 10 to $30 \mathrm{~cm}$ thick. The overlying material consists of sand and clay and shows the characteristic red tinge in most places. Such sediments are from 1 to $5 \mathrm{~m}$ thick.

Residual gem-bearing beds contain material deposited mostly in situ. These are located on flat and sloping regions bordering the ridges and away from the rivers. The sediments are found on weathered rocks, which sometimes manifest a lateritic character. The gem-bearing sediments consist mainly of angular quartz pebbles, sand, clay and sub-rounded pebbles. Gravel - to pebble - size corundum grains with clear crystal contours are characteristic of these gem-bearing beds, which have thicknesses ranging from $10 \mathrm{~cm}$ to $3 \mathrm{~m}$. The overlying material varying in thickness from 1 to $6 \mathrm{~m}$ is composed mainly of sandy clay with the characteristic reddish brown tinge. The overlying material often displays lateritic character and bedding.
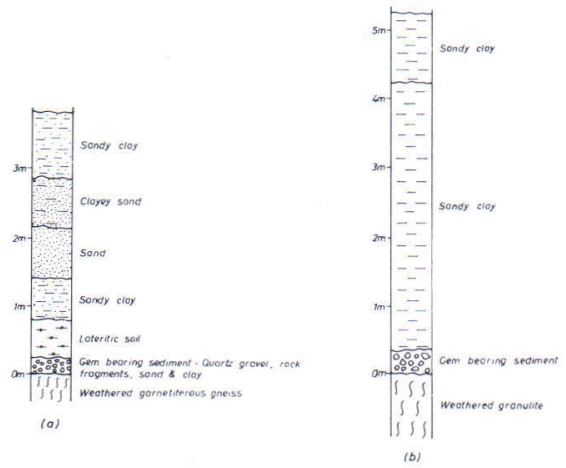

Fig. 5. Stratigraphic sections of gem pits - Kalu Ganga (a) alluvial type (b) residual type. 
Table 1. Mean weight percentage of minerals in the $-80+120$ fraction of the sediments and associated rocks of the study areas. $n=$ no. of samples studied.

\begin{tabular}{|c|c|c|c|c|c|c|c|c|c|c|c|c|c|c|c|c|}
\hline \multirow[b]{3}{*}{ Mineral } & \multicolumn{8}{|c|}{ Weddagala area } & \multicolumn{8}{|c|}{ Kalu Ganga area } \\
\hline & \multicolumn{2}{|c|}{$\begin{array}{c}\text { Gem sediments } \\
(\mathrm{n}=25)\end{array}$} & \multicolumn{2}{|c|}{$\begin{array}{l}\text { Garnetiferous } \\
\text { gneiss }(\mathrm{n}=08)\end{array}$} & \multicolumn{2}{|c|}{$\begin{array}{l}\text { Granulite } \\
(n=06)\end{array}$} & \multicolumn{2}{|c|}{$\begin{array}{c}\text { Charnockite } \\
(n=04)\end{array}$} & \multicolumn{2}{|c|}{$\begin{array}{c}\text { Gem sediments } \\
(\mathrm{n}=12)\end{array}$} & \multicolumn{2}{|c|}{$\begin{array}{l}\text { Garnetiferous } \\
\text { gneiss }(n=04)\end{array}$} & \multicolumn{2}{|c|}{$\begin{array}{l}\text { Granulite } \\
(\mathrm{n}=03)\end{array}$} & \multicolumn{2}{|c|}{$\begin{array}{c}\text { Charnockite } \\
(n=04)\end{array}$} \\
\hline & $\begin{array}{l}\text { Mean } \\
\text { value }\end{array}$ & $\begin{array}{l}\text { Range of } \\
\text { values }\end{array}$ & $\begin{array}{l}\text { Mean } \\
\text { value }\end{array}$ & $\begin{array}{l}\text { Range of } \\
\text { values }\end{array}$ & $\begin{array}{l}\text { Mean } \\
\text { value }\end{array}$ & $\begin{array}{l}\text { Range of } \\
\text { values }\end{array}$ & $\begin{array}{l}\text { Mean } \\
\text { value }\end{array}$ & $\begin{array}{l}\text { Range of } \\
\text { values }\end{array}$ & $\begin{array}{l}\text { Mean } \\
\text { value }\end{array}$ & $\begin{array}{l}\text { Range of } \\
\text { values }\end{array}$ & $\begin{array}{l}\text { Mean } \\
\text { value }\end{array}$ & $\begin{array}{l}\text { Range of } \\
\text { values }\end{array}$ & $\begin{array}{l}\text { Mean } \\
\text { value }\end{array}$ & $\begin{array}{l}\text { Range of } \\
\text { values }\end{array}$ & $\begin{array}{l}\text { Mean } \\
\text { value }\end{array}$ & $\begin{array}{l}\text { Range of } \\
\text { values }\end{array}$ \\
\hline Andalusite & 0.07 & $0-0.3$ & 0.02 & $0-0.07$ & - & - & - & - & 0.07 & $0-0.41$ & - & - & - & - & 0.01 & $0-0.03$ \\
\hline $\begin{array}{l}\text { Apatite } \\
\text { A }\end{array}$ & - & - & 0.08 & $0-0.61$ & 0.021 & $0-0.05$ & - & - & - & - & - & - & - & - & 0.04 & $0-0.07$ \\
\hline Biotite & - & - & 7.60 & $0-38.97$ & 1.51 & $0-8.93$ & 2.70 & $0.03-5.36$ & - & - & 2.89 & $0.36-4.14$ & 3.51 & $2.13-5.19$ & 20.83 & $15.71-26.73$ \\
\hline Corundum & 0.532 & $0-1.5$ & 0.07 & $0-0.43$ & 0.46 & $0.14-0.65$ & 0.41 & $0.26-0.85$ & 4.25 & $0-12.18$ & 0.08 & $0.04-0.14$ & 0.04 & $0.00-00.08$ & 1.38 & $1.05-1.68$ \\
\hline $\begin{array}{l}\text { Diopside } \\
\text { Dide }\end{array}$ & - & - & - & - & & - & 13.15 & $0.40-50.37$ & 0.098 & $0-18.12$ & - & - & - & - & - & - \\
\hline Garnet & 3.28 & $1-7$ & 20.13 & $0.21-80.02$ & 2.95 & $0.24-15.2$ & 4.06 & $1.68-7.67$ & 7.58 & $0-20.68$ & 18.47 & $21.21-25.23$ & 1.48 & $0.78-2.13$ & - & - \\
\hline Hornblende & - & - & 0.13 & $0-0.61$ & 0.51 & $0-1.21$ & 1.62 & $0-3.90$ & 3.54 & $0-10.98$ & - & - & - & - & 6.54 & $1.02-10.20$ \\
\hline Hypersthene & - & - & 0.37 & $0-2.31$ & - & - & 28.42 & $0-70.25$ & 2.32 & $0-8.23$ & - & - & 0.13 & $0-0.39$ & 60.68 & $53.45-63.23$ \\
\hline Ilmenite & 51.44 & $30-74$ & 18.59 & $0.68-50.98$ & 45.17 & $19.82-55.68$ & 32.79 & $0-65.73$ & 20.55 & $0.44-46.50$ & 10.96 & $6.23-14.25$ & 13.0 & $3.90-27.01$ & - & - \\
\hline Leucoxene & - & - & 6.31 & $1.52-18.03$ & 4.011 & $0.16-8.71$ & - & - & 0.41 & $0-2.80$ & - & - & - & - & - & - \\
\hline Limonite & - & - & 24.61 & $0-74.46$ & 3.661 & $0.10-16.31$ & - & - & - & - & - & - & - & - & - & - \\
\hline Magnetite & $13 . \overline{92}$ & $0-31$ & $\begin{array}{r}5.01 \\
5.02\end{array}$ & $0.06-25.86$ & 8.13 & $0.14-13.01$ & 5.20 & $0-18.68$ & 1.98 & $0.19-5.48$ & 1.04 & $0-2.91$ & 1.67 & $0.95-2.12$ & - & - \\
\hline Monazite & 4.36 & $1-50$ & 0.13 & $0-00.63$ & 0.3 & $0.18-0.41$ & - & - & 0.32 & $0-1.10$ & 3.49 & $1.15-6.84$ & 4.78 & $0-7.73$ & - & - \\
\hline Muscovite & $\begin{array}{l}2.30 \\
2.84\end{array}$ & $\begin{array}{l}1-30 \\
1-9\end{array}$ & 3.25 & $0-12.28$ & 0.07 & $\begin{array}{c}.10-0.41 \\
0-0.31\end{array}$ & - & - & - & - & - & - & - & - & - & - \\
\hline Pyrite & 0.06 & $0-1.0$ & 0.22 & $0-1.36$ & - & - & - & - & - & - & - & - & - & - & - & - \\
\hline Rutile & 3.98 & $0-9$ & 1.15 & $0-4.63$ & 3.15 & $0-4.51$ & - & - & 2.55 & $0.91-5.76$ & 1.54 & $0.11-3.21$ & 1.40 & $0.33-2.33$ & - & - \\
\hline Secondary & - & 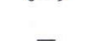 & 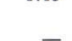 & - & 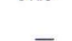 & - & - & - & 798 & $0-51.15$ & 40.69 & $2989-5923$ & 4382 & $3801-6547$ & - & 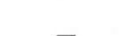 \\
\hline $\begin{array}{l}\text { Iron ore } \\
\text { Sillimanite }\end{array}$ & $12 . \overline{28}$ & $3-29$ & $3 . \overline{22}$ & $0-12.12$ & $23 . \overline{58}$ & $16.81-28.33$ & $4 . \overline{54}$ & $0-7.87$ & $\begin{array}{r}.9 .98 \\
25.73\end{array}$ & $\begin{array}{r}0-71.19 \\
11.00-74.88\end{array}$ & $\begin{array}{l}40.69 \\
16.60\end{array}$ & $\begin{array}{r}29.89-59.23 \\
8.74-20.21\end{array}$ & $\begin{array}{l}4.82 \\
16.19\end{array}$ & $\begin{array}{r}28.01-63.41 \\
1.21-29.12\end{array}$ & $5 . \overline{80}$ & $4.82-6.71$ \\
\hline Sphene & - & - & -2 & - & - & - & 0.0025 & $0-0.01$ & 0.12 & $0-0.14$ & - & - & & - & - & _ \\
\hline Spinel & $2 . \overline{16}$ & $1-4$ & $2 . \overline{47}$ & $0.08-19.10$ & 0.07 & $0-0.17$ & - & - & 20.58 & $1.22-51.04$ & 0.53 & $0-2.11$ & 9.18 & $0-27.55$ & 0.0025 & $0-0.01$ \\
\hline Topaz & 0.98 & $0-1.5$ & - & $0-0.58$ & 0.915 & $0.48-1.11$ & 0.17 & $0-0.32$ & 0.30 & $0-1.08$ & 0.095 & $0-0.23$ & 0.263 & $0.03-0.62$ & - & - \\
\hline Tourmaline & 1.46 & $0-2.6$ & - & $0-4.46$ & 0.58 & $0.06-2.31$ & - & - & 0.12 & $0-0.58$ & - & - & 0.053 & 0.016 & - & - \\
\hline Tremolite & - & - & - & - & - & - & - & - & 0.07 & $0-0.75$ & - & - & - & - & - & - \\
\hline Zircon & 3 & $1-5$ & - & $0-3.26$ & 2.90 & $1.39-4.46$ & 1.42 & $0-4.53$ & 0.61 & $0-2.03$ & 3.64 & $0.84-6.24$ & 2.40 & $0-7.21$ & - & - \\
\hline
\end{tabular}


Table 2. Mean volume percentage of minerals in thin sections of rocks of the study area. (from visual estimations) $\mathrm{n}=\mathrm{no}$. of samples studied.

\begin{tabular}{|c|c|c|c|c|c|c|c|c|c|c|c|c|}
\hline \multirow[b]{3}{*}{ Mineral } & \multicolumn{6}{|c|}{ Weddagala area } & \multicolumn{6}{|c|}{ Kalu Ganga area } \\
\hline & \multicolumn{2}{|c|}{$\begin{array}{l}\text { Garnetiferous gneiss } \\
\qquad(\mathrm{n}=08)\end{array}$} & \multicolumn{2}{|c|}{$\begin{array}{c}\text { Granulite } \\
(\mathrm{n}=09)\end{array}$} & \multicolumn{2}{|c|}{$\begin{array}{l}\text { Charnockite } \\
\quad(n=04)\end{array}$} & \multicolumn{2}{|c|}{$\begin{array}{l}\text { Garnetiferous gneiss } \\
\qquad(\mathrm{n}=06)\end{array}$} & \multicolumn{2}{|c|}{$\begin{array}{c}\text { Granulite } \\
(\mathrm{n}=06)\end{array}$} & \multicolumn{2}{|c|}{$\begin{array}{l}\text { Charnockite } \\
(n=04)\end{array}$} \\
\hline & $\begin{array}{l}\text { Mean } \\
\text { value }\end{array}$ & $\begin{array}{l}\text { Range of } \\
\text { values }\end{array}$ & $\begin{array}{l}\text { Mean } \\
\text { value }\end{array}$ & $\begin{array}{l}\text { Range of } \\
\text { values }\end{array}$ & $\begin{array}{l}\text { Mean } \\
\text { value }\end{array}$ & $\begin{array}{l}\text { Range of } \\
\text { values }\end{array}$ & $\begin{array}{l}\text { Mean } \\
\text { value }\end{array}$ & $\begin{array}{l}\text { Range of } \\
\text { values }\end{array}$ & $\begin{array}{l}\text { Mean } \\
\text { value }\end{array}$ & $\begin{array}{l}\text { Range of } \\
\text { values }\end{array}$ & $\begin{array}{l}\text { Mean } \\
\text { value }\end{array}$ & $\begin{array}{c}\text { Range of } \\
\text { values }\end{array}$ \\
\hline Apatite & - & - & - & - & - & - & - & - & - & - & - & - \\
\hline Biotite & 4.25 & $2-8$ & 0.55 & $0-5$ & 2.25 & $0-8$ & 2.5 & $0-5$ & 4 & $3-5$ & 0.75 & $0-3$ \\
\hline Diopside & 0.38 & $0-3$ & 2.22 & $0-20$ & 1.5 & $0-6$ & - & - & - & - & - & - \\
\hline Garnet & 13.75 & $5-25$ & 1.89 & $0-8$ & 2 & $0-4$ & 9.33 & $5-20$ & 3.16 & $2-5$ & - & - \\
\hline Hornblende & - & - & - & - & 1.75 & $0-4$ & - & - & - & - & 2 & $0-3$ \\
\hline Hypersthene & - & - & - & - & 6.25 & $0-8$ & - & - & - & - & 7.75 & $5-10$ \\
\hline Microcline & - & - & 12 & $0-35$ & - & - & - & - & - & - & - & - \\
\hline Microperthite & 3.5 & $0-10$ & 8.33 & $0-30$ & 7.5 & $0-30$ & - & - & - & - & 5 & $0-10$ \\
\hline Muscovite & - & - & - & - & - & - & - & - & - & - & - & - \\
\hline Opaque minerals & - & - & - & - & - & - & - & - & - & - & - & - \\
\hline Orthoclase & 26.25 & $15-40$ & 15 & $0-35$ & 10 & $0-20$ & 16.67 & $5-25$ & 8.33 & $5-20$ & 13.75 & $5-20$ \\
\hline Plagioclase & 13.13 & $10-20$ & 15.55 & $0-55$ & 12 & $0-25$ & 14.16 & $5-20$ & 17.5 & $10-25$ & 36.25 & $30-40$ \\
\hline Quartz & 35.63 & $25-60$ & 42.78 & $25-60$ & 53.75 & $50-60$ & 56.67 & $30-65$ & 61.67 & $50-70$ & 33.75 & $30-40$ \\
\hline Rutile & - & - & 0.33 & $0-3$ & - & - & - & - & - & - & - & - \\
\hline Sillimanite & - & - & - & - & - & - & - & - & - & - & - & - \\
\hline Sphene & - & - & 0.33 & $0-3$ & - & - & - & - & - & - & - & - \\
\hline Zircon & - & - & - & - & - & - & - & - & - & - & - & - \\
\hline
\end{tabular}




\section{Observations on the mineralogy of rocks and sediments}

The weight percentages of heavy minerals in the $-80+120$ fractions of gem sediments ( $\mathrm{Ta}$ bles 1 and 2) in both study areas reveal that corundum is associated with large amounts ilmenite and sillimanite. In the Weddagala sediments, the other important associated minerals are garnet, magnetite, spinel, topaz, tourmaline and zircon. In the Kalu Ganga area, the sediments show a marked decrease in topaz and tourmaline. However, exceptional amounts of hypersthene, sillimanite and spinel are noted.

Thin section studies of garnetiferous gneisses, granulites and charnockites indicated a general dominance of quartz over the total feldspar content. However, the charnockites of the Kalu Ganga area manifested a marked decrease in their quartz content in favour of high feldspar values. These rocks also showed significant amounts of hypersthene and sillimanite. The heavy mineral fraction $(-80+120)$ of the said charnockites exhibited appreciable amounts of corundum associated with biotite, hornblende and hypersthene. The granulites of Weddagala showed moderate quantities of corundum with topaz and zircon, whereas those of Kalu Ganga were poor in such minerals. In the garnetiferous gneisses of Weddagala, the heavies showed important values for garnet, topaz, tourmaline and zircon with corundum as a minor mineral. In the Kalu Ganga gneisses, tourmaline was not observed whereas the other gem minerals were present in comparable proportions. The marble and pegmatite bodies of the study areas were found to be poor in gem minerals and significantly devoid of corundum.

Our observations on gem sediments lead us to recognize the following gem and other mineral assemblages for the two study areas:

Weddagala: corundum, garnet, spinel, topaz, tourmaline and zircon with ilmenite, magnetite, monazite, muscovite, rutile and sillimanite.

Kalu Ganga: corundum, garnet, spinel, topaz and zircon with hornblende, hypersthene, ilmenite, magnetite, rutile and sillimanite.

\section{Discussion}

Geological and mineralogical studies of the popular gemming areas of Sri Lanka show that gem minerals such as corundum, garnet, spinel, topaz, tourmaline and zircon are found in residual, eluvial and alluvial deposits or in combinations of these types. As their source, the minerals have high temperature - pressure facies rocks such as garnetiferous gneiss, granulite and charnockite in association with quartzite, marble and amphibolite. Such rock suites are characteristic of the Highland Group of Sri Lanka, and further studies on gemstones should necessarily be concentrated in this Precambrian terrain (Fig. 1). Indeed, occurrences of gemstones in the central highlands are currently being reported.

Study of the heavy mineral fractions of sediments and rocks indicates that gem minerals, particularly the principal Sri Lankan gemstone, corundum, is associated with hypersthene, muscovite and sillimanite with appreciable amounts of biotite and hornblende. Except for charnockites, the other two rock types are highly feldspathic and could well be described as aluminous. It is to be noted that charnockites are found intimately associated with granulites and garnetiferous gneisses in conformity with local foliation and also as boudins; cross-cutting structures were not found. The presence of discontinuous charnockitic and amphibolitic bands in gneisses and granulites tends to imply silllike, lit-par-lit injected basic bodies in these aluminous rock suites. It is interesting to note here that most of the world's gem mineralizations are associated with basic and pelitic bodies with sources of heat available for the formation of corundum (Parkinson 1947; Friedman 1956; Deer et al. 1962; Morrison 1972 and Anhaeusser 1974). In the present study areas, too, basic 
charnockites are associated with aluminous rocks, and the presence of sillimanite, muscovite and hypersthene in appreciable quantities in both rocks and sediments attests to the availability of high temperature and pressure conditions during the formation of the Highland rock suites. Furthermore, most of the other reported occurrences of corundum in Sri Lanka also indicate the existence of basic and pelitic bodies in association with a probable source of heat. As postulated by Munasinghe and Dissanayake (1981), a desilication process could well occur owing to contact metamorphic effects resulting from charnockitic and other basic intrusions into aluminous sediments. Perhaps, a detailed petrological and geochemical study within and around charnockitic bodies would help to establish the nature of the process or processes that had governed the formation of corundum in appreciable quantities in the metasedimentary sequences of the Highland Group of rocks, which could be classified under the pyroxene granulite sub-facies of de Waard (1965).

\section{Conclusions}

The present study suggests: (a) garnetiferous gneiss, granulite and charnockite as the source rocks of Sri Lankan gem minerals - corundum, garnet, spinel, topaz, tourmaline and zircon; (b) the formation of corundum, the principal Sri Lankan gem mineral, due to metamorphism of aluminous sediments under pyroxene granulite facies PT conditions in contact with basic bodies, thus triggering off a desilication process.

Acknowledgements. The writers gratefully acknowledge Sri Lanka National Science Council research grant No. $\mathrm{RG} / 79 / 20$ for one of them. (K. D.). Mr. Sarath Perera is thanked for his help in the laboratory. Mr. S. M. B. Amunugama and Mrs. S. J. Wijesekera kindly drafted the figures and Mr. K. Dunuhappawa's services in typing an earlier draft of this manuscript are remembered with gratitude.

\section{References}

Anhaeusser, C. R., 1974. The nature of chrysolite asbestos occurrences in Southern Africa - a review. Johannesburg, Univ. Witwatersrand, Econ. Geol. Research Unit. Inf. Circ. 90, 238 p.

Coates, J. S., 1935. The geology of Ceylon: Ceylon Jour. Sci. 19, 101-187.

Cooray, P. G., 1978. Geology of Sri Lanka, in Nutalaya, P., ed., Proceedings of 3rd Regional Conf. Geology and Mineral Resources of Southeast Asia. Bangkok, 701710.

Cooray, P. G. \& Kumarapeli, P. S., 1960. Corundum from biotite-sillimanite gneiss from near Polgahawela, Ceylon. Geol. Mag., 97, 480--487.

de Waard, 1965. A proposed subdivision of the granulite facies. Amer. J. Sc., 263, 455-461.

Dahanayake, K. \& Ranasinghe, A. P., 1981. Source rocks of gem minerals - A case study from Sri Lanka. Mineralium Deposita 16, 103-111.

Dahanayake, K.; Liyanage, A. N. \& Ranasinghe, A. P.,

1980. Genesis of sedimentary gem deposits in Sri Lanka. Sedimentary Geol., 25, 105-115.

Deer, W. A.; Howie, R. A. \& Zussman, J., 1962. Rockforming minerals. New York, John Wiley, v. 1-5.

Friedman, G. M., 1956. The origin of spinel-emery deposits with particular reference to those of the Cortland complex, New York. New York State Museum Bull., 5, 35 p.

Hapuarachchi, D. J. A. C., 1975. The granulite facies of Sri Lanka. Sri Lanka Geol. Survey Dept. Prof. Paper 4, $29 \mathrm{p}$.

Jayawardena, D. E. de S. \& Carswell, D. A., 1976. The geochemistry of charnockites and their constituent ferromagnesian minerals from the Precambrian of Southeast Sri Lanka. Mineralogical Mag., 40, 541-554.

Katz, M. B., 1972. Facies series of the high-grade metamorphic rocks of the Ceylon Precambrian. Int. Geol. Cong. 24th, Montreal 1972, Sec. 2, 43-51.

Morrison, E. R., 1972. Corundum in Rhodesia. Rhod. Geol. Survey Min. Res. Series 16, 24 p.

Munasinghe, T.\& Dissanayake, C. B., 1981. The origin of 
Geology and mineralogy of gemming terrains of Sri Lanka 149

gemstones of Sri Lanka. Econ. Geol., 76, 1216-1225. Parkinson, J., 1947. Outlines of the geology of the Mtito Andei - Tsavo area, Kenya colony. Kenya Geol. Survey Report 13 (M. A. 11-56), 23 p.

Silva, K. K. M. W., 1976. Some geological aspects of the
Elahera gem field, Sri Lanka (abs.). Sri Lanka Ass. Adv. Sc., 32nd Annual Sessions.

Wells, A. J., 1956. Corundum from Ceylon. Geol. Mag. 93, 25-31. 